\title{
PENGARUH LAYANAN INFORMASI PRIBADI SOSIAL TERHADAP DISIPLIN BELAJAR SISWA
}

\author{
ZUMMY ANSELMUS DAMI \\ Program Studi Bimbingan dan Konseling \\ Fakultas Keguruan dan Ilmu Pendidikan \\ Universitas PGRI Nusa Tenggara Timur \\ Jl. Perintis Kemerdekaan III/40, Kupang, Nusa Tenggara Timur, Indonesia \\ E-mail: rzummy.dami@yahoo.com
}

\begin{abstract}
ABSTRAK
Layanan informasi pribadi sosial sangat perlu diadakan untuk membekali para siswa dengan pengetahuan yang baik yang berkaitan dengan kedisiplinan baik yang berkaitan dengan pribadisosial maupun belajar, agar kedepannya peserta didik tidak lagi mengalami kesulitan-kesulitan karena mereka telah dibekali dengan pengetahuan yang bermanfaat bagi diri dan lingkiungan hidupnyalebih mampu mengatur dan merencanakan kehidupannya sendiri. Informasi yang diterima juga memungkinkan peserta didik untuk menentukan arah hidupnya, mengambil keputusan tentang masa depannya dan bertanggung jawab atas pilihan yang telah di buat. Untuk menciptakan insan yang berkualitas tentu yang sangat dituntut perannya dalam hal ini adalah pendidikan formal agar sedini mungkin setelah menanamkan nilai-nilai baik pada seluruh siswanya. Tujuan dari penelitian ini yaitu untuk mengetahui pngaruh layanan informasi pribadi sosial terhadap disiplin belajar peserta didik di SMP Negeri 9 Kota Kupang Tahun Pelajaran 2015/2016. Langkah-langkah yang digunakan untuk menentukan sampel: Metode pengumpulan data menggunakan metode survei dengan teknik kuesioner Penelitian ini diteliti hanya 40 orang siswa.Teknik sampel yang dipergunakan dalam penelitian ini adalah saturation sample, yaitu mempergunakan keseluruhan anggota dalam sebuah populasi, yang berarti dalam penelitian ini melibatkan 40 orang siswa sebagai sampel.Hasil uji hipotesis menunjukkan bahwa layanan informasi karir memenuhi kriteria signifikan $(0.000<0.05)$, ini berarti bahwa terdapat pengaruh yang signifikan antara layanan informasi pribadi sosial dengan disiplin belajar.
\end{abstract}

Keywords: pengaruh, layanan, informasi, pribadi, sosial, disiplin, belajar

\section{PENDAHULUAN}

Pendidikan merupakan kebutuhan bagi setiap manusia agar menjadi manusia yang berdaya guna. Dalam Undang-Undang RI No. 20 Tahun 2003 tentang Sistem Pendidikan Nasional, Pasal 1 Ayat (1) disebutkan bahwa pendidikan adalah usaha sadar dan terencana untuk mewujudkan suasana belajar dan proses pembelajaran agar peserta didik secara aktif mengembangkan potensi dirinya untuk memiliki kekuatan spiritual keagamaan, pengendalian diri, kepribadian, kecerdasan, akhlaq mulia, serta ketrampilan yang diperlukan dirinya, masyarakat, Bangsa dan Negara.

Sekolah merupakan lingkungan pendidikan sekunder. Bagi anak yang sudah bersekolah, maka lingkungan yang setiap hari dimasukinya selain lingkungan rumah adalah lingkungan sekolahnya. Anak remaja yang sudah duduk di SLTP pada umumnya menghabiskan waktu sekitar 7 jam sehari disekolahnya. Ini berarti bahwa hamper sepertiga dari waktunya setiap hari dilewatkan remaja 
disekolahnya. Tidak mengherankan kalau pengaruh sekolah terhadap remaja cukup besar (Sarwono, 2004:124). Lingkungan sekolah sangat berperan penting dalam perkembangan wawasan dan ilmu pengetahuan seseorang yang menjadikannya sebagai manusia yang berkualitas. Apabila pada saat ini perkembangan zaman semakin pesat sehingga menuntut generasi muda untuk menguasai segala cabang ilmu pengetahuan agar menjadi insan yang berkualitas dan berguna bagi nusa dan bangsa. Untuk menciptakan insan yang berkualitas tentu yang sangat dituntut perannya dalam hal ini adalah pendidikan formal agar sedini mungkin setelah menanamkan nilai-nilai baik pada seluruh siswanya. Salah satu upaya pendidikan formal dalam mencapai keberhasilan tersebut dan mudah dalam pencapaian tujuan yang diharapkan adalah menetapkan peraturan-peraturan agar seluruh komponen disiplin.

Pada masa remaja banyak sekali perubahan yang terjadi pada diri anak, baik segi psikis maupun fisiknya. Dalam segi psikis banyak teori-teori perkembangan yang memaparkan gangguan emosi dan gangguan perilaku sebagai akibat dari tekanan-tekanan yang dialami remaja karena perubahan-perubahan yang terjadi pada dirinya maupun akibat perubahan pada lingkungan. Jika tidak diwaspadai, perubahan-perubahan psikis yang terjadi sebagai tugas perkembangan remajaitu akan berdampak negatif pada remaja. Terutama dalam pergaulan remaja, baik itu di lingkungan tempat tinggal, sekolah dan masyarakat luas pasti terdapat suatu etika. Etika sering disebut sebagai filsafat moral, dimana etika merupakan nilai-nilai dan norma-norma moral yang menjadi pegangan bagi seseorang atau suatu kelompok dalam mengatur tingkah laku. Seiring dengan perkembangan zaman semakin lama etika tersebut mulai luntur, terutama pada peserta didik sekolah menengah pertama. Peserta didik biasanya memiliki karakter yaitu sikap menentang nilai dan norma yang ada di sekolah dan masyarakat. Salah satu sikap peserta didik yang menentang etika adalah peserta didik yang mulai bergaul sesuka hatinya, baik dari cara berpakaian yang tidak rapi, cara bertutur kata yang tidak menghiraukan kesopanannya baik dengan guru maupun dengan teman, dan sering melanggar peraturan sekolah.

Tindakan peserta didik yang sering melanggar aturan tersebut bertentangan dengan etika baik bagi dirinya sendiri maupun bagi masyarakat. Peserta didik yang melakukan pelanggaran etika tersebut, karena peserta didik sendiri kurang mengerti dan memahami tentang nilai-nilai yang terkandung di dalam lingkungan sekitarnya serta kurangnya teladan yang baik yang bisa di jadikan contoh untuk dirinya agar dapat memiliki etika pergaulan yang baik sesuai dengan nilai-nilai moral yang ada di lingkungan sekitarnya.

Berbagai layanan informasi yang diselenggarakan disekolah pada umumnya adalah informasi pribadi, informasi sosial, informasi belajar dan informasi karir. Dan sasaran tersebut diberikan kepada peserta didik, guru bidang studi, wali kelas, orang tua/wali, dan masyarakat. Layanan BK disini untuk membantu peserta didik agar dapat menyelesaikan masalah-masalah yang dihadapinya melalui potensi yang dimilikinya.

Seorang guru terutama guru bimbingan dan konseling, berperan secara langsung terhadap siswa dalam mengembangkan potensinya karena layanan bimbingan dan konseling merupakan bagian yang integral dalam proses pendidikan nasional, akan tetapi untuk mengembangkan potensi peserta didik tidak dapat berjalan dengan sendirinya karena untuk mendapat potensi yang diharapkan, menjadi tanggungjawab bersama setiap personil disekolah, serta dibutuhkan arahan dan dorongan dari keluarga, dimulai dari tugas-tugas sebagai remaja. Salah satu yang perlu diperhatikan untuk mendapatkan potensi diri sesuai dengan usia dan tugas-tugasnya adalah 
lingkungan pergaulan siswa dan bagaimana menempatkan dirinya di lingkungan terutama dalam pergaulan siswa di sekolah. Proses belajar dijadikan sebagai situasi perangsang sosial, maka diperlukan kemampuan menyesuaikan diri, siswa diharapkan bisa mencapai tujuan dalam bidang sosial maupun akademik yang disebut juga dengan "tri sukses" yaitu sukses akademik, sukses hubungan sosial, dan sukses persiapan karir.

Dalam hal ini layanan informasi sangat perluh diadakan untuk membekali para siswa dengan pengetahuan yang baik yang berkaitan dengan kedisiplinan baik yang berkaitan dengan pribadi-sosial maupun belajar, agar kedepannya peserta didik tidak lagi mengalami kesulitan-kesulitan karena mereka telah dibekali dengan pengetahuan yang bermanfaat bagi diri dan lingkiungan hidupnyalebih mampu mengatur dan merencanakan kehidupannya sendiri.

Informasi yang diterima juga memungkinkan peserta didik untuk menentukan arah hidupnya, mengambil keputusan tentang masa depannya dan bertanggung jawab atas pilihan yang telah di buat. Untuk menciptakan insan yang berkualitas tentu yang sangat dituntut perannya dalam hal ini adalah pendidikan formal agar sedini mungkin setelah menanamkan nilai-nilai baik pada seluruh siswanya.

Salah satu upaya peendidikan formal dalam mencapai keberhasilan tersebut dan mudah dalam pencapaian tujuan yang diharapkan adalah menetapkan peraturanperaturan agar seluruh komponen disiplin.

Dalam hal ini yang dimaksud dengan disiplin adalah mengikuti dan mentaati peraturan, nilai, dan hukum yang berlaku (Tu'u 2004:33). Disiplin diperoleh oleh siapa saja dimanapun seseorang berada selalu ada peraturan dan tata tertib. Manusia sangat membutuhkan disiplin dalam hidupnya karena jika manusia hidup tanpa disiplin akan timbul berbagai permasalahan dalam kehidupannya seharihari dan segala prilakunya tidak sesuai dengan peraturan yang berlaku ditempat ia berada. Bagi para siswa, apabila disiplin dikembangkan dan diterapkan dengan baik, konsisten, dan konsekuen akan berdampak positif bagi kehidupan dan prilaku siswa. Disiplin dapat mendorong siswa belajar secara konkret dan praktis hidup disekolah tentang hal-hal positif dan menjauhi hal-hal yang negatif. Disiplin siswa akan terlihat dari kepatuhannya dan ketatannya dalam mematuhi peraturan sekolah. Lingkungan sekolah yang disiplin akan melahirkan siswa-siswa yang berprestasi karena siswa yang terbiasa dalam lingkungan yang disiplin akan membawa hidupnya menjadi teratur, tertib, tertata dengan baik dan mengantarkan siswa sukses dalam belajar.

Berdasarkan observasi yang di lakukan peneliti pada hari rabu 02 Agustus 2016 di SMP Negeri 9 Kota Kupang, peneliti menemukan ketidak disiplin yang ditunjukan siswa ketika berada dalam kelas maupun di luar kelas, hal tersebut terlihat ketika guru memberikan penjelasan di depan kelas kebanyakan siswa tidak mendengar penjelasan guru, sering membuat keributan dalam kelas ketika pelajaran sedang berlangsung, keluar dari kelas tanpa meminta izin, membuang sampah di sembarangan tempat, jarang mengerjakan PR di rumah, sering mengerjakan PR di sekolah, sering menyontek ketika ujian, tidak teratur ketika melakukan apel pagi dan apel siang. Berbagai masalah yang di temukan di atas dapat dikategorikan siswa belum memahami sepenuhnya mengenai disiplin.

Di lihat dari teori Tu'u yang menjelaskan disiplin yang diterapkan dengan baik disekolah akan memberikan andil bagi pertumbuhan dan perkembangn prestasi siswa. Penerapkan disiplin sekolah akan mendorong motivasi dan memaksa para siswa bersaing meraih prestasi. 


\section{KAJIAN LITERATUR DAN PEGEMBANGAN HIPOTESIS Layanan Informasi Pribadi Sosial Pengertian Layanan Informasi}

Juntika, dan Akur (2005: 20) Layanan informasi adalah layanan yang memberikan sejumlah informasi kepada peserta didik. Tujuan layanan ini agar peserta didik memiliki informasi yang memadai, baik informasi tentang dirinya maupun informasi tentang lingkungannya. Informasi yang diterima oleh siswa merupakan bantuan dalam menyesuaikan diri dalam pergaulan di sekolah. Pelaksanaan layanan informasi di sekolah merupakan salah satu layanan yang dapat menjadikan tujuan pendidikan dapat tercapai secara optimal, karena layanan yang diberikan oleh konselor di sekolah di upayakan untuk membantu memecahkan permasalahan yang di hadapi peserta didik.

Prayitno dalam Mulyadi, ( 2004: 22) menyatakan bahwa: Layanan informasi, yaitu layanan bimbingan dan konseling yang memugkinkan peserta didik ( klien ) menerima dan memahami berbagai informasi ( seperti informasi pendidikan dan informasi jabatan ) yang dapat di gunakan sebagai bahan pertimbangan dan pengambilan keputusan untuk kepentingan peserta didik.

Sejalan dengan pendapat tersebut Winkel dan Hastuti (2006 : 316-317) menyatakan bahwa: "Layanan informasi adalah usaha untuk membekali para peserta didik dengan pengetahuan tentang data dan fakta di bidang pendidikan sekolah, bidang pekerjaan dan bidang perkembangan pribadi-soaial supaya mereka dapat belajar tentang lingkungan hidupnya lebih mampu mengatur dan merencanakan kehidupanya sendiri".

Berdasarkan pendapat para ahli diatas tersebut dapat disimpulkan bahwa layanan informasi adalah untuk membekali peserta didik dengan pengetahuan dan informasi yang berguna untuk menyelesaikan masalah yang dihadapinya, baik berkenaan dengan maslah pribadi, sosial, belajar dan karir. Informasi yang diterima juga memungkinkan peserta didik untuk menentukan arah hidupnya, mengambil keputusan tentang masa depannya dan bertanggung jawab atas pilihan yang telah di buat. Pada pelaksanaan pemberian layanan bimbingan konseling di sekolah memiliki alasan tersendiri mengapa layanan informasi harus diberikan.

Prayitno dan Amti ( 2004: 260) menyatakan bahwa ada tiga alasan utama mengapa informasi harus diberikan :

a) Membekali individu dengan berbagai pengetahuan tentang lingkungan yang diperlukan untuk menyelesaikan masalah yang dihadapi berkenaan dengan lingkungan sekitar, pendidikan, jabatan, maupun sosial budaya.

b) Memugkinkan individu dapat menentukan arah hidupnya. Berdasarkan informasi yang di perolehnya peserta didik dapat membuat rencana-rencana dan keputusan tentang masa depanya, serta bertanggung jawab atas rencana dan keputusan yang telah dibuat.

c) Setiap individu itu unik. Keunikan itu akan berakibat perbedaan pada polapola pengambilan keputusan dan tindakan berada dari individu sesuai dengan aspek kepribadian masingmasing individu. Dengan demikian akan tercipta dinamika perkembangan individu dan masyarakat berdasarkan potensi positif yang ada pada diri individu dan masyarakat. Sejalan dengan pendapat tersebut Daud (2011/03/29) menyatakan bahwa:

a) Membekali siswa dengan berbagai pengetahuan tentang lingkungan yang di perlukan untuk menyelesaikan masalah yang di hadapi berkenaan dengan lingkungan sekitar, pendidikan, jabatan, maupun sosial budaya.

b) Memungkinkan siswa dapat menentukan arah hidupnya. Berdasarkan informasi yang di perolehnya peserta didik dapat membuat rencana-rencana dan 
keputusan tentang masa depannya, serta bertanggung jawab atas rencana dan keputusan yang telah di buat.

c) Setiap individu itu unik. Keunikan itu akan berakibat perbedaan pada polapola pengambilan keputusan dan tindakan berada dari individu sesuai dengan aspek kepribadian masingmasing individu. Dengan demikian akan tercipta dinamika perkembangan individu dsan masyarakat berdasarkan potensi positif yang ada pada diri individu dan masyarakat.

\section{Layanan Informasi Pribadi Sosial}

Menurut Hartono (2010), kemandirian Layanan pemberian informasi diadakan untuk membekali para siswa dengan pengetahuan tentang data dan fakta di bidang pendidikan sekolah, bidang pekerjaan dan bidang perkembangan pribadi-sosial, supaya mereka dengan belajar tentang lingkungan hidupnya lebih mampu mengatur dan merencanakan kehidupannya sendiri. Program bimbingan yang tidak memberikan layanan pemberian informasi akan menghalangi peserta didik untuk berkembang lebih jauh, karena mereka membutuhkan kesempatan untuk mempelajari data dan fakta yang dapat mempengaruhi jalan hidupnya. Namun, mengingat luasnya informasi yang tersedia dewasa ini, mereka harus mengetahui pula informasi manakah yang relevan untuk mereka dan mana yang tidak relevan, serta informasi macam apa yang menyangkut data dan fakta yang tidak berubah dan ada yang dapat berubah dengan beredarnya roda waktu.

Juntika dan Akur (2004: 12) Bimbingan Pribadi merupakan upaya pengembangan kemampuan peserta didik untuk menghadapi masalah-masalah pribadi dengan cara menciptakan lingkungan pendidikan yang kondusif serta pemahaman diri.

Sedangkan Juntika dan Akur (2004:12) Bimbingan Sosial merupakan upaya peserta didik di dalam memecahkan masalah-masalah sosial seperti berinteraksi dengan pergaulan, diharapkan dapat menyelesaikan konflik dan dapat menyesuaikan diri secara wajar dan positif terhadaplingkungan yang ada.

Berdasarkan pembahasan di atas dapat disimpulkan bahwa layanan informasi pribadi sosial merupakan layanan yang memberikan sejumlah informasi kepada siswa dalam hal yang berkaitan dengan kemempuan mengenal dan mengembangkan potensi diri dalam menghadapi masalah-masalah di lingkungan hidupnya, seperti berinteraksi dengan pergaulan, di harapkan dapat menyelesaikan konflik, dan dapat menyesuaikan diri secara wajar dan dapat bertanggung jawabdengan keputusan yang dibuat.

Rahma (2012) dalam pelaksanaan layanan informasi mencakup bidang pribadi, sosial, dan belajar.

1. Layanan informasi dalam bidang pribadi meliputi, kegiatan pemberian informasi tentang:

a) Tugas-tugas perkembangan masa remaja, khususnya tentang kemampuan dan perkembangan pribadi.

b) perlunya pengembangan kebiasaan dan sikap dalam keimanan dan ketakwaan terhadap Tuhan Yang Maha Esa.

c) Usaha-usaha yang dapat dilakukan dalam mengenal bakat, minat, serta bentuk-bentuk pembinaan, pengembangandan penyaluranya.

d) Perlunya hidup sehat dan upaya melaksanakanya.

e) Usaha yang dapat dilakukan melalui bimbingan dan konseling dalam membantu siswa menghadapi masa peralihan yang penuh tantangan.

2. Layanan informasi dalam bimbingan sosial meliputi, kegiatan pemberian informasi tentang:

a) Tugas perkembangan masa remaja tentang pengembangan hubungan sosial

b) Cara bertingkah laku, sopan santun 
c) Tata krama pergaulan dengan teman sebaya

d) Suasana dan tata krama kehidupan dalam berkeluarga

e) Hak dan kewajiban warga negara

f) Pengenalan dan manfaat lingkungan yang lebih luas.

3. Layanan informasi dalam bimbingan belajar meliputi, kegiatan pemberian informasi tentang:

a) Pemantapan sikap dan kebiasaan belajar yang efektif dan efisien serta produktif,baik dalam mencari informasi dari berbagai sumber belajar, bersikap terhadap guru dan narasumber lainnya, mengembangkan keterampilan belajar, mengerjakan tugas-tugas pelajaran dan menjalani program penilaian hasil belajar.

b) Pemantapan disiplin belajar dan berlatih, baik secara mandiri maupun berkelompok.

c) Pemantapan penguasaan materi program belajar di sekolah menengah pertama sesuai dengan perkembangan ilmu, teknologi dan kesenian.

d) Pemantapan pemahaman dan pemanfaatan kondisi fisik, sosial dan budaya yang ada di sekolah, lingkungan sekitar dan masyarakat untuk pengembangan pengetahuan dan kemampuan serta pengembangan pribadi.

\section{Tujuan Pemberian Layanan Informasi Pribadi Sosial}

Setiap pemberian layanan di sekolah tentu saja memiliki tujuan sendiri begitu pula dengan pelaksanaan layanan informasi yang di berikan oleh konselor di sekolah. Secara khusus layanan bimbingan dan konseling bertujuan untuk membantu siswa agar dapat mencapai tujuan-tujuan perkembangan meliputi aspek pribadisosial, belajar, dan karir. Bimbingan pribadi-sosial dimaksudkan untuk mencapai tujuan dan tugas perkembangan pribadi-sosial dalam mewujudkan pribadi yang takwa, mandiri dan bertanggung jawab. Bimbingan belajar dimaksudkan untuk mencapai tujuan dan tugas perkembangan pendidikan.

Yusuf (2006: 14), secara rinci menyebutkan tujuan yang ingin dicapai dari bimbingan pribadi sosial antara lain:

a) Memiliki komitmen yang kuat dalam mengamalkan nilai- nilai keimanan dan ketaqwaan kepada Tuhan Yang maha Esa, baik dalam kehidupan pribadi, keluarga, pergaulan dengan teman sebaya, sekolah, tempat kerja maupun masyarakat pada umumnya.

b) Memiliki sikap toleran terhadap umat beragama lain dengan saling menghormati dan memelihara hak dan kewajibannya masing-masing.

c) Memiliki pemahaman tentang irama kehidupan yang bersifat fluktuatif antara yang menyenangkan (anugrah), dan yang tidak menyenangkan (musibah), serta mampu meresponnya secara positif sesuai dengan ajaran agama yang dianut.

d) Memiliki pemahaman dan penerimaan diri secara objektif dan konstruktif, baik yang berkaitan dengan keunggulan maupun kelemahan, baik fisik maupun psikis.

e) Memiliki sikap positif atau respek terhadap diri sendiri dan orang lain.

f) Memiliki kemampuan melakukan pilihan secara sehat.

g) Bersikap respek terhadap orang lain, menghormati atau menghargai orang lain, tidak melecehkan martabat atau harga dirinya.

h) Memiliki rasa tanggun jawab, yang diwujudkan dalam bentuk komitmen terhadap tugas atau kewajibannya.

i) Memiliki kemampuan berinteraksi sosial (human relationship), yang diwujudkan dalam bentuk hubungan persahabatan, 
persaudaraan, atau silaturahmi dengan sesama manusia.

j) Memiliki kemampuan dalam menyelesaikan konflik (masalah) baik bersifat internal (dalam diri sendiri) maupun dengan orang lain.

k) Memiliki kemampuan dalam mengambil keputusan secar efektif

Sejalan dengan pendapat tersebut tentang tujuan pelaksanaan layanan informasi bagi peserta didik di sekolah. Arsitun (2011/03/29) menyatakan bahwa: Layanan informasi bertujuan agar siswa yang mendapatkan informasi bisa menambah wawasan dan bila perlu dapat dipergunakan sebagai bahan pertimbangan untuk mengambil keputusan bagi siswa. Berdasarkan pendapat tersebut dapat disimpulkan bahwa tujuan layanan informasi adalah untuk membantu peserta didik dalam mengatasi masalah serta pengambilan keputusan melalui pemberian layanan informasi.

\section{Fungsi Layanan Informasi Pribadi Sosial}

Prayitno dan Amti (2004: 199) fungsi bimbingan dan konseling di tinjau dari kegunaan atau mamfaat ataupun keuntungan-keuntungan yang diperoleh dari layanan bimbingan dan konseling adalah sebagai berikut:

1) Fungsi pemahaman

Fungsi pemahaman yang perlu dihasilkan dalam bimbingan dan konseling adalah pemahaman tentang diri konseli beserta permasalahannya oleh konseli sendiri dan oleh pihak-pihak yang akan membantu konseli, serta pemahaman tentang lingkungan konseli oleh konseli.

2) Fungsi Pencegahan

Fungsi pencegahan adalah upaya untuk membuat lingkungan menjadi positif, sehingga tidak menimbulkan kesulitan atau kerugian bagi individu.

3) Fungsi Pengentasan

Upaya pengentasan melalui pelayanan bimbingan dan konseling adalah dengan mengeluarkan seseorang dari posisi yang tidak mengenakkan,yang dampaknya dapat mengganggu perkembangan siswa.
4) Fungsi Pemeliharan dan
pengembangan

Fungsi pemeliharaan berarti memelihara segala sesuatu yang baik yang ada pada individu, baik itu pembawaan atau hasil perkembangan. Pemeliharaan yang baik akan sekedar mempertahankan agar apa yang ada tetap baik, tetapi juga mengembangkan agar yang ada berkembang menjadi lebih baik.

\section{Disiplin Belajar Pengertian Disiplin Belajar}

Rahman (2011:64) mengatakan bahwa disiplin berasal dari bahasa Inggris "discipline" yang mengandung beberapa arti. Diantaranya adalah pengendalian diri, membentuk karakter yang bermoral, memperbaiki dengan sanksi, serta kumpulan beberapa tata tertib untuk mengatur tingkah laku.

Rahman (2011:66) mengatakan Disiplin juga merupakan upaya untuk membentuk tingkah laku sesuai dengan yang sudah ditetapkan untuk mencapai sesuatu yang lebih baik dan diharapkan. Terkait itu, sekolah yang punya tata tertib jelas bermaksud mendisiplinkan guru dan peserta didik untuk mencapai tingkat tertinggi dalam prestasi belajar-mengajar.

Moenir (2010:94) “ Disiplin adalah suatu bentuk ketaatan terhadap aturan, baik tertulis maupun tidak tertulis yang telah ditetapkan." Moenir (2010:95-96) Disiplin ada dua jenis, yaitu disiplin waktu dan disiplin perbuatan yaitu: Mengenai disiplin ada dua jenis yang sangat dominan dalam usaha menghasilkan barang dan jasa sesuai dengan apa yang dikehendaki organisasi. Kedua disiplin itu adalah disiplin dalam hal waktu dan disiplin dalam hal kerja atau perbuatan. Kedua jenis disiplin tersebut merupakan kesatuan yang tidak dapat dipisahkan serta saling mempengaruhi. Dapat saja seseorang hadir tepat waktu, tetapi tidak segera melakukan perbuatan sesuai ketentuan 
organisasi pada hakekatnya merugikan organisasi.

Disiplin mendorong siswa belajar secara konkrit dalam praktik hidup di sekolah maupun dirumah. Seperti dikemukakan Moenir (2010:95) bahwa "Melalui disiplin yang tinggi pelaksanaan suatu ukuran dapat mencapai maksud dan dapat dirasakan manfaatnya oleh semua pihak." Sedangkan belajar merupakan suatu proses perubahan yaitu perubahan tingkah laku sebagai hasil dari interaksi dengan lingkungannya dalam memenuhi kebutuhan hidupnya.

Slameto (2010:67), mengemukakan bahwa "Agar siswa belajar lebih maju, siswa harus disiplin di dalam belajar baik di sekolah, dirumah dan diperpustakaan. "Dari pendapat tersebut, dapat diartikan disiplin dapat membuat siswa belajar lebih maju dan dengan kemajuan yang diperoleh tersebut maka akan meningkatkan hasil belajar siswa.

Berdasarkan berbagai uraian diatas dapat disimpulkan bahwa disiplin belajar merupakan setiap macam pengaruh yang ditunjukan untuk membantu peserta didik agar dia dapat memahami dan menyesuaikan diri dengan tuntutan lingkungannya dan juga penting tentang cara menyelesaikan tuntutan yang mungkin ingin ditunjukkan peserta didik terhadap lingkungannya. Untuk mengukur tingkat disiplin belajar siswa diperlukan indikator-indikator mengenai disiplin belajar.

\section{Aspek Pengukuran Disiplin Belajar}

Moener (2010:96), aspek yang dapat digunakan untuk mengukur tingkat disiplin belajar siswa berdasarkan ketentuan disiplin di rumah dan disiplin di sekolah, yaitu:

1. Disiplin belajar di rumah meliputi:

a) Membuat jadwal kegiatan di rumah

b) Menyiapkan dan membenahi mata pelajaran yang akan di pelajari besok

c) Mengerjakan PR yang telah diberikan guru di sekolah d) Bangun pagi-pagi dan bersiap-siap untuk berangkat ke sekolah

2. Disiplin belajar di sekolah meliputi:

a) Datang ke sekolah tepat waktu

b) Mentaati peraturan di sekolah

c) Mengikuti upacara dengan tertip

d) Mengumpulkan tugas yang diberikan guru dengan tepat waktu

e) Melakukan tugas piket sesuai jadwalnya.

\section{Manfaat Disiplin Belajar}

Dalam kehidupan sehari-hari telah terdapat keyakinan bahwa anak memerlukan sedikit disiplin agar ia dapat bertingkah laku sesuai dengan standar norma masyarakat dan agar ia dapat diterima dalam lingkungan masyarakat. Dengan disiplin anak dapat belajar bertingkah laku sesuai tuntutan masyarakat dan dapat diterima di lingkkungannya. Disiplin bermanfaat bagi anak-anak utnuk perkembangan karena dengan disiplin beberpa kebutuhan akan terpenuhi. Seperti dikatakan oleh Dirk Meyer, Gutkin dan Redh (Oteng Sutisna,) bahwa manfaat dari disiplin adalah:

Disiplin memberi rasa aman dan memberitahukan apa yang boleh dan tidak boleh dilakukan

1. Dengan membantu anak menghindari perasaan bersalah, rasa malu akibat perilaku yang salah, perasaan yang pasti mengakibatkan rasa tidak bahagia dan penyesuaian yang baik terhadap disiplin memungkinkan anak hidup menurut standar yang disetujui oleh lingkungan sosialnya dan dengan demikian memperoleh prsetujuan sosial.

2. Dengan disiplin anak belajar bersikap menurut cara yang akan mendatangkan pujian yang akan ditampilkan anak sebagai tanda kasih sayang dan penerimaan hal ini esensial bagi penyesuaian yang berhasil dan berakhir dengan kebahagiaan.

3. Disiplin yang sesuai dengan perkembangan berfungsi sebagai motivasi pendorong ego yang 
mendorong anak mencapai apa yang diharapkan dirinya.

Disiplin membantu anak mengembangkan hati nurani, suara dari dalam, pembimbing dan pengambilan keputusan dan pengendalian perilaku. Menurut Oemar Hamalik belajar adalah kegiatan-kegiatan fisik badaniah. Hasil belajar yang dicapai yang dicapai adalah berupa perbedaan dalam fisik itu, misalnya mencapai kecakapan motorik, seperti berlari, mengendari mobil, memukul secara baik dan sebagainya. Pendapat lain menitikberatkan pendapatnya bahwa belajar adalah kegiatan rohani atau psikis. Hasil belajar yang dicapai perubahanperubahan dalam psikis. Misalnya memperoleh pengertian tentang bahasa, mengapresiasikan seni budaya, bersikap susila dan lain-lain. Muhibbin Syah berpendapat bahwa belajar adalah tahapan perubahan tingkah laku individu yang relatif menetap sebagai hasil pengalaman dan interaksi dengan lingkungan yang melibatkan proses kognitif.

Penjelasan di atas menunjukkan adanya dua pandangan mengenai belajar, pertama menekankan pada pelatihan fisik. Kedua menekankan pada pelatihan pembentukan aspek psikis. Dan dapat digaris bawahi bahwa perubahan hasil tersebut bukan disebabkan oleh obat-obatan, hasil pertumbuhan atau kematangan, melainkan perubahan tersebut terjadi akibat latihan dan pengalaman, misalnya perubahan pengetahuan, kecakapan dan tingkah laku serta keterampilan. Apabila kedua istilah itu disatukan, dengan pertimbangan batasan masing-masing, maka disiplin belajar dapat dipandang sebagai kadar karakteristik dan keadaan serba teraturnya upaya seseorang dalam proses merubah pengetahuan, pemahaman, sikap dan tingkah laku, keterampilan, kecakapan dan kemampuan individu serta merubah aspekaspek lainnya yang ada dalam individu yang sedang belajar. Dengan kata lain disiplin belajar adalah pengendalian sikap mental yang mengarah pada upaya menaati peraturan dan tata tertib yang ada dalam proses merubah kognitif, afektif dan psikomotor. Ketika kegiatan belajar mengajar berlangsung, kadang-kadang siswa berprilaku tidak disiplin, sehingga mendatangkan masalah bagi guru dan teman-temannya. Padahal guru tidak mengharapkan berhadapan dengan masalah-masalah ketidak disiplinan selama berlangsungnya kegiatan belajar mengajar.

\section{Hipotesis}

Hipotesis dalam penelitian ini dapat dirumuskan sebagai berikut:

1. Hipotesis alternatif (Ha): ada pengaruh layanan informasi pribadi sosial terhadap disiplin belajar siswa kelas VIII di SMP Negeri Kota Kupang Tahun Pelajaran 2015/2016.

2. Hipotesis Nol (Ho): tidak ): ada pengaruh layanan informasi pribadi sosial terhadap disiplin belajar siswa kelas VIII di SMP Negeri Kota Kupang Tahun Pelajaran 2015/2016.

\section{METODE PENELITIAN}

Metode penelitian yang digunakan dalam penelitian ini adalah metode "Kuantitatif" diartikan sebagai metode yang dilandaskan pada filsafat positivisme digunakan untuk meneliti pada populasi atau sampel tertentu, pengambillan sampel dilakukan secara random, pengumpulan data menggunakan instrumen, analisis data bersifat statis dengan tujuan untuk menuju hipotesis yang ditetapkan. (Sugiyono 2013:14). Penelitian kuantitatif ini diarahkan untuk mengetahui pengaruh intensitas layanan informasi pribadi sosial terhadap kedisiplinan belajar pada peserta didik di SMP Negeri 9 Kota Kupang Tahun Pelajaran 2015/2016.

\section{Populasi, Sampel dan Teknik Pengambilan Sampel. Populasi dan Sampel}

Populasi adalah keseluruan objek penelitian. Menurut Sugiyono (2013:123) populasi adalah wilaya generalisasi yang 
terdiri atas subjek atau objek yang mempunyai kuantitas dan karakteristik tertantu yang ditetapkan oleh peneliti untuk dipelajari dan kemudian ditarik kesimpulan.

Adapun populasi dalam penelitian ini adalah seluruh siswa kelas VIII h dan VIII i SMP Negeri 9 Kota Kupang, yang terdiri dari 49 orang. Sampel merupakan bagian dari populasi yang akan diteliti. Menurut sugiyono (2013:81), teknik pengambilan sampel menggunakan teknik sampling jenuh dimana anggota populasi dijadikan sampel dalam penelitian ini adalah berjumlah 40 orang.

Alasannya karena ketika pembagian skala 9 siswa di dua kelas tersebut tidak hadir. Oleh karena itu, dalam penelitian ini di teliti hanya 40 orang siswa.

Teknik sampel yang dipergunakan dalam penelitian ini adalah saturation sample, yaitu mempergunakan keseluruhan anggota dalam sebuah populasi, yang berarti dalam penelitian ini melibatkan 40 orang siswa sebagai sampel. Kriteria sampel adalah (1) sampel berada di bawah kesatuan kebijakan administratif yang sama; (2) sampel mempunyai kompensasi yang sama; (3) sampel memiliki kurikulum yang sama; (4) sampel melaksanakan kegiatan-kegiatan ekstra kurikulum yang sama; (5) sampel berada di bawah kondisi kerja yang sama.

\section{Teknik Pengumpulan Data}

Metode pengumpulan data menggunakan metode survei dengan teknik kuesioner.Lebih lajut, teknik kuesioner/angket dimaksudkan untuk mengukur layanan informasi pribadi sosial dan disiplin belajar. Sebelum kuesioner dibagikan secara langsung, peneliti terlebih dahulu memberikan penjelasan kepada para responden secara bersamasama item per item. Peneliti juga melakukan tindakan pendampingan kepada responden di dalam melakukan penilaian. Hal ini dilakukan agar tidak diperoleh jawaban yang bias dari responden, sehingga dapat diasumsikan bahwa jawaban yang diberikan oleh responden sesuai dengan kenyataan yang sebenarnya. Selain itu juga untuk menjamin terkumpulnya kembali sesuai dengan jumlah angket yang dibagikan.

\section{Teknik Analisis Data}

Uji Asumsi Klasik

Uji Normalitas

Uji normalitas dilakukan untuk menguji apakah dalam model regresi, variabel pengganggu atau residual memiliki distribusi normal, seperti diketahui bahwa uji $\mathrm{t}$ dan $\mathrm{F}$ mengasumsikan bahwa nilai residual mengikuti distribusi normal. Kalau asumsi ini dilanggar maka uji statistik menjadi tidak valid untuk jumlah sampel kecil (Ghozali, 2009). Pengujian normalitas dilakukan dengan melihat grafik histogram, P-P Plot Test, dan uji one sampel kolmogorov-smirnov. Pada uji kolmogorov-smirnov apabila nilai signifikansi $>0,05$ maka dapat disimpulkan data nilai residual terdistibusi normal. Normalitas P-P Plot Test dideteksi dengan melihat titik-titik yang mengikuti garis linear yang bergerak dari bawah keatas, sehingga bila titik-titik tersebut mengikuti garis linear, berarti data terdistribusi normal, dan analisis dapat dilanjutkan (Santoso, 2000).

\section{Uji Multikolonieritas}

Uji Multikolonieritas bertujuan untuk menguji apakah model regresi ditemukan adanya korelasi antar variabel bebas (independen). Dalam pengertian sederhana setiap variabel independen menjadi variabel dependen (terikat) dan di regresi terhadap variabel independen lain. Pengujian ini akan dilakukan dengan melihat pada nilai tolerance dan Varians inflation factor (VIF). Nilai yang umumnya untuk menunjukkan adanya multikolonieritas adalan nilai tolerance $\leq$ 0.10 dengan nilai VIF $\geq 10$ (Ghozali, 2009). 


\section{Uji Heteroskedastisitas}

Uji heteroskedastisitas bertujuan untuk menguji apakah dalam model regresi terjadi ketidaksamaan variance dari residual satu pengamatan ke pengamatan yang lain. Jika variance dari residual satu pengamatan ke pengamatan yang lain tetap, maka disebut homoskesdatisitas. Salah satu cara untuk mendeteksi ada atau tidaknya heteroskedastisitas yaitu dengan melihat grafik plot antara nilai prediksi variabel terikat (dependen) yaitu ZPRED dengan redualnya SRESID. Deteksi ada tidaknya heteroskedastisitas dapat dilakukan dengan melihat ada tidaknya pola tertentu pada grafik scatterplot antara SRESID dan ZPRED dimana sumbu $\mathrm{Y}$ adalah sumbu $Y$ yang telah diprediksi, dan sumbu $X$ adalah residual yang telah di studentized (Ghozali, 2009).

\section{Uji Linearitas}

Uji linearitas dilakukan untuk mengetahui linearitas hubungan antara variabel bebas dengan variabel terikat dan untuk mengetahui signifikansi penyimpangan dari linieritas hubungan tersebut. Jika penyimpangan tersebut tidak signifikan, maka hubungan antara variabel bebas dengan variabel terikat adalah linear (Hadi, 2000). Hasil uji linieritas dengan p>0.05 maka dapat dikatakan adanya hubungan yang linear antara variabel bebas dengan variabel terikat.

\section{Uji Hipotesis}

Uji regresi linear sederhana bertujuan untuk menganalisis dan mengetahui pengaruh kedua variabel $(\mathrm{x}, \mathrm{y})$ dalam bentuk sebuah presentasi yang mewakili kedua variabel tersebut. Kedua variabel dicari dengan persamaan regresi.

\section{HASIL DAN PEMBAHASAN}

Pengujian hipotesis menggunakan regresi berganda.
Tabel 4.1

Hasil Uji Hipotesis

Coefficients $^{\mathrm{a}}$

\begin{tabular}{|c|c|c|c|c|c|c|}
\hline \multirow[t]{2}{*}{ Model } & & \multicolumn{2}{|c|}{$\begin{array}{c}\text { Unstandardized } \\
\text { Coefficients } \\
\end{array}$} & \multirow{2}{*}{$\begin{array}{l}\text { Stand } \\
\text { ardize } \\
\mathrm{d} \\
\text { Coeffi } \\
\text { cients } \\
\text { Beta }\end{array}$} & \multirow[b]{2}{*}{$t$} & \multirow[b]{2}{*}{ Sig. } \\
\hline & & B & $\begin{array}{l}\text { Std. } \\
\text { Error }\end{array}$ & & & \\
\hline 1 & $\begin{array}{l}\text { (Constant) } \\
\text { Layanan } \\
\text { Pribadi } \\
\text { Sosial }\end{array}$ & $\begin{array}{l}28.093 \\
.402\end{array}$ & $\begin{array}{l}4.967 \\
.086\end{array}$ & .605 & $\begin{array}{l}5.656 \\
4.683\end{array}$ & $\begin{array}{l}.000 \\
.000\end{array}$ \\
\hline
\end{tabular}

a. Dependent Variable: disiplin belajar

Pada Tabel 4.1 diketahui bahwa dari variabel yang dimasukan ke dalam model regresi, yaitu layanan informasi karir memenuhi kriteria signifikan (pvalue<0.05).ini berarti bahwa terdapat pengaruh yang signifikan antara layanan informasi pribadi sosial dengan disiplin belajar.

Secara umum hasil pengukuran diatas membuktikan bahwa hipotesis penelitian yang menyatakan bahwa layanan informasi pribadi sosial berpengaruh positif terhadap disiplin belajar peserta didik di SMP Negeri 9 Kota Kupang dapat diterima. Hal ini didukung dengan hasil penelitian dengan uji statistika $\mathrm{F}$ (uji signifikan) dengan nilai $\mathrm{F}$ hitung sebesar 21,926 peda taraf signifikansi 0,000 $(p<0,05)$. Jadi, layanan informasi pribadi sosial memiliki pengaruh signifikan terhadap disiplin belajar peserta didik dengan nilai $\mathrm{R}$ square sebesar 0,366 atau $36,6 \%$. Dengan demikian disiplin belajar peserta didik di SMP Negeri 9 Kota Kupang di pengaruhi oleh layanan informasi pribadi sosial sebesar $36,6 \%$ dan sisanya sebesar $60,34 \%$ di terangkan oleh variabel yang lain. Sementara itu koefisien regresi layanan informasi prinadi sosial bernilai positif yaitu sebesar 0,402, yang berarti bahwa terdapat pengaruh positif layanan informasi pribadi sosial terhadap disiplin belajar peserta didik. Dengan kata lain makin tinggi layanan informasi pribadi sosial maka akan 
berdampak pada meningkatnya disiplin belajar peserta didik sebesar 0,402. Sebaliknya makin rendah layanan informasi pribadi sosial maka rendahnya disiplin belajar peserta didik di SMP Negeri 9 Kota Kupang. Hasil penelitian di SMP Negeri 9 Kota Kupangmenunjukan bahwa layanan informasi pribadi sosial memberikan hasil yang signifikan terhadap disiplin belajar peserta didik. Layanan informasi pribadi sosial merupakan layanan yang memberikan sejumlah informasi kepada siswa dalam hal yang berkaitan dengan kemampuan mengenal dan mengembangkan potensi diri dalam menghadapi masalah-masalah dalam lingkungan hidupnya, serta berinteraksi dengan pergaulan, diharapkan dapat menyelesaikan konflik, dan dapat menyesuaikan diri dengan wajar dan dapat bertanggung jawab dengan keputusan yang telah dibuat. Layanan informasi pribadi sosial memberi pengaruh yang signifikan terhadap disiplin belajar peserta didik di SMP Negeri 9 Kota Kupang. Hasil ini dapat dilihat dari hasil uji t pada tabel 4.8 $\mathrm{B}=0,402$ dari hasil penelitian ini, menunjukan bahwa layanan informasi pribadi sosial berpengaruh pada disiplin belajar peserta didik.

Peserta didik di SMP Negeri 9 Kota Kupang memiliki disiplin belajar yang positif karena salah satu faktornya yaitu layanan informasi pribadi sosial yang baik. Hal ini berarti lingkungan sekolah SMP Negeri 9 Kota Kupang berpotensi untuk menumbuhkan disiplin belajar yang positif bagi peserta didiknya, karena besarnya layanan informasi pribadi sosial sehingga mereka mampu membangun relasi dalam sebuah kelompok dan aktif dalam kegiatan ekstrakurikuler sehingga mereka dapat membangun rasa saling percaya pada teman dan lingkungannya.

Disiplin belajar menunjukkan suatu kondisi yang tercipta dan terbentuk melalui proses usaha yang dilakukan seseorang untuk memperoleh suatu perubahan tingkah laku yang baru secara keseluruhan, sebagai hasil dari pengalamannya sendiri dalam interaksi dengan lingkungan yang menunjukan nilai-nilai kataatan, kepatuhan, kesetiaan, keteraturan, dan ketertiban. Oleh karena itu, peserta didik yang memiliki disiplin yang baik akan bermanfaat bagi dirinya dan orang lain seperti yang di kemukakan oleh Dirk Meyer, Gutkin dan Redh (Oteng Sutisna) bahwa disiplin memberikan rasa aman dan membantu anak menghindari perasaan bersalah, rasa malu akibat perilaku yang salah, dan memotivasi anak mencapai apa yang diharapkan dirinya.

\section{KESIMPULAN}

Layanan informasi pribadi sosial mempunyai pengaruh positif terhadap disiplinan belajar peserta didik, artinya semakin sering siswa diberikan layanan informasi pribadi sosial maka akan semakin baik atau meningkat kedisiplinan belajar yang ditunjukkan peserta didik.

\section{REFERENSI}

Alfabeta, Sugiyono. 2013. Statistik Untuk Penelitian. Bandung: Alfabeta

Amti Erman dan Prayitno. 2013. Layanan Bimbingan Dan Konseling Kelompok. Jakarta : PT. Rinrka Cipta.

Arikunto, Suharsimi dkk. (2006). Penelitian Tindakan Kelas. Jakarta: Bumi Askara.

Arikunto, Suharsimi. (2010). Prosedur Penelitian Suatu Pendekatan Praktik.Edisi revisi.Jakarta: PT. Rineka Cipta.

Bimo, Walgito. (2004). Pengantar Psikologi Umum. Andi. Jakarta.

Daud Abu. (2011). Layanan Penguasaan Konten. Tersedia di internet di ambil pada jam 16:15 WIB Tanggal 04 Februari 2013. 
Ghozali, I. (2001). Aplikasi analisis multivariate dengan program SPSS. Semarang: Badan Penerbit Universitas Diponegoro.

Gunarsa, Y. dan Singgih D. (2004). Psikologi untuk muda- mudi. Jakarta: Gunung Mulia

Hamalik, Oemar. (2004). Proses Belajar Mengajar. Bumi Aksara. Jakarta.

Hariastuti, Retno Tri. (2008). DasarDasar Bimbingan dan Konseling. Jakarta: Unesa University Press.

Hurlock,

E.B.

(2007)

PsikologiPerkembangan.Alih bahasa oleh Soedjarmo \&Istiwidayanti.Jakarta: Erlangga.

Jalaludin. (2015). Psikologi Komunikasi. Bandung: Rosda Karya

Maman Rahman, 1999. Manajemen kelas. Jakarta: Depdiknas, Proyek Pendidikan Guru SD.

Margono. (2010). Metodologi Penelitian Pendidikan, Jakarta: PT. Rineka Cipta.

Mugiarso, Heru. (2005). Bimbingan dan Konseling. Semarang : UPT MKDK Universitas Negeri Semarang.

Muhaimin, Azzet Akhmad. (2011). Bimbingan \& Konseling di Sekolah. Jogjakarta : Ar-Ruzz Media.

Nurihsan, Juntika dan Yusuf Syamsu. (2005). Landasan Bimbingan dan Konseling. Bandung: PT. Remaja Rosda Karya.
Nurihsan, Juntika. (2006). Bimbingan dan konseling dalam berbagai latar kehidupan. Bandung: Refika Aditama.

Nurihsan, J. dan Yusuf, S. (2010). Landasan Bimbingan dan Konseling.Bandung: PT Remaja Rosda Karya.

Prayitno. (1995). Layanan Bimbingan Konseling Kelompok Dasar dan Profil. Jakarta: PT Gramedia Pustaka Utama

Republik Indonesia.Undang-Undang Sistem Pendidikan Nasional Nomor 20 Tahun 2003.

Sarwono, S. Wirawan (2006). Psikologi Remaja, Jakarta: PT Raja Grafindo Persada.

Slameto. (2010). Belajar dan FaktorFaktor yang Mempengaruhinya. Jakarta: Rineka Cipta.

Soegeng Prijodarminto, 1994. Disiplin, Kiat menuju Sukses. Jakarta: Abadi.

Sugiyono,(2012). Statistik Untuk Penelitian.Alfabeta: Bandung.

Sugiyono. (2013). Metode Penelitian Pendidikan (Pendidikan Kuantitatif, Kualitatif, dan $R \& D)$. Bandung: Rosda Karya.

Sukmadinata, Nana Syaodiyah. 2003. Landasan Psikologi Proses Pendidikan. Bandung: Remaja Rosdakarya.

Suryabrata, Sumadi. 2002. Psikologi Kpribadian. Jakarta: Rajawali.

Syamsul Bachri Thalib, Psikologi Pendidikan Berbasis Analisi 
Empiris Aplikatif, (Jakarta: Kencana,( 2010).

Tirtonegoro, Sutratinah. 2001. Anak Supernormal dan Program Pendidikannya. Jakarta : Bumi Aksara

Tohirin. (2007). Bimbingan dan Konseling di Sekolah dan Madrasah. Jakarta: Grafindo Persada.

Tulus Tu'u, 2004. Peran Disiplin pada Perilaku dan Prestasi Siswa. Jakarta: PT. Gramedia

Wahyuni, Sri. 2010. Pengaruh lingkungan belajar dan Kecerdasan Spiritual terhadap Prestasi belajar ekonomi pada siswa kelas X SMA Muhammadiyah 2 Surakarta tahun ajaran 2009/2010.(Skripsi S1). Surakarta: UMS

Winkel. (1981). Bimbingan dan Penyuluhan di Sekolah Menengah. Jakarta: Gramedia.

Winkel. (1997). Bimbingan dan Konseling di Institusi Pendidikan Edisi Revisi.Jakarta: PT Gramedia,

Winkel dan Sri Hastuti. (2004). Bimbingan dan Konseling di Institusi Pendidikan. Yogyakarta: Media Abadi.

Winkel, W.S dan Sri Hastuti. (2006). Bimbingan dan konseling di institusi pendidikan. Jakarta: PT. Grasindo.

Witherington, Cart. 2003. Psikologi Pendidik Terjemahan Purwanto. Jakarta: Remaja Rosdakarya.

Yusuf, LN. Syamsu. (2006). Psikologi Perkembangan Anak dan Remaja. Bandung: Rosda.

Yusuf, Syamsu. Dan Nurihsan, Juntika. (2005). Landasan Bimbingan dan Konseling. Bandung: Rosda Karya.

Yusuf, Syamsu. Dan Nurihsan, Juntika. (2008). Teori Kepribadian. Bandung: PT. Remaja Rosdakarya.

Yusuf, Syamsu. 2010. Program Bimbingan dan Konseling di Sekolah. Bandung: Rizqi. 